\title{
Notes
}

\section{Religious Exemptions Under the Free Exercise Clause: A Model of Competing Authorities}

Many religious individuals feel profoundly trapped between the demands of their faith and the laws of the state. The relief that such persons often seek is exemption from laws that, although constitutionally sound, nevertheless infringe upon their religious beliefs. The basis for such relief can be found in the free exercise clause of the First Amendment. ${ }^{1}$

Claims for religion-based exemptions under the free exercise clause do not fit easily into American constitutional jurisprudence. Most constitutional rights involve norms internal to society's value system. Grants of religion-based exemptions, in contrast, require that the state accommodate itself to external norms of conduct or just treatment. ${ }^{2}$

Present free exercise doctrine, which has allowed some exemptions under a balancing test derived from other aspects of First Amendment law, is ad hoc and conceptually flawed. Courts ap-

1. U.S. Const. amend. I ("Congress shall make no law ... prohibiting the free exercise [of religion].") The Supreme Court declared the free exercise clause applicable to the states in Cantwell v. Connecticut, 310 U.S. 296, 303 (1940).

The question of religion-based exemptions from otherwise constitutional laws is a distinct issue within free exercise doctrine. $C f$. Galanter, Religious Freedoms in the United States: $A$ Turning Point? 1966 WIs. L. Rev. 217, 217-18, 231 (singling out freedom from "admittedly 'secular' regulations"). Courts also apply the free exercise clause to hold unconstitutional laws that discriminate on the basis of religion, see, e.g., Cruz v. Beto, 405 U.S. 319 (1972) (prison must provide Buddhist reasonable opportunity to pursue his faith comparable to that afforded other prisoners); Fowler v. Rhode Island, 345 U.S. 67 (1953) (Jehovah's Witnesses meeting may not be barred in public park open to other religious services), or that exceed the permissible scope of government regulation, see, e.g., West Va. State Bd. of Educ. v. Barnette, 319 U.S. 624 (1943) (state may not compel students to recite pledge of allegiance); Murdock v. Pennsylvania, 319 U.S. 105 (1943) (state may not impose license requirement on door-to-door distribution of religious literature). This Note refers to such findings of unconstitutionality, in contrast to the granting of religion-based exemptions, as the "general application" of the free exercise clause.

2. The fundamental decision to consider religion-based exemptions is itself founded upon society's internal norms, but any particular claim for an exemption is derived from the specific tenet of the claimant's religion. The uniqueness of religion-based exemptions as a constitutional issue is highlighted by contrasting it with free speech doctrine. See United States v. O'Brien, 391 U.S. 367, 376 (1968) (refusing to accept "the view that an apparently limitless variety of conduct can be labeled 'speech' whenever the person engaging in the conduct intends thereby to express an idea"). 
plying it have been insufficiently generous in granting exemptions, and even when they have allowed them, have been prone to make inappropriate substantive judgments.

A central premise of this Note is that religious liberty, as enshrined in the free exercise clause, is a pure value that should be promoted to the greatest extent possible in a pluralistic society. ${ }^{3}$ The Note argues that religion-based exemptions are necessary to a sysıem of religious liberty, yet can be understood only by looking beyond standard constitutional principles. The Note first examines the defects of current exemption doctrine. It then argues that the courts should adopt instead a doctrine of "competing legal authorities." That doctrine employs an analogy to the legal discipline of conflict of laws, which has long grappled with claims based upon externally derived norms. Finally, the Note suggests procedures by which courts could apply the doctrine of competing authorities.

\section{The Inadequacy of Religious Exemption Doctrine}

Claims for religion-based exemptions have been lodged against a variety of laws, including driver's license photograph requirements, ${ }^{4}$ compulsory education requirements, ${ }^{5}$ tax laws, ${ }^{6}$ unemployment insurance rules, ${ }^{7}$ narcotics statutes, ${ }^{8}$ civil rights statutes, ${ }^{9}$

3. See Abington School Dist. v. Schempp, 374 U.S. 203, 223 (1963) (purpose of free exercise clause is to "secure religious liberty in the individual by prohibiting any invasions thereof by civil authority"). The guarantee of religious liberty is nurtured in part by a substantive commitment to the protection of religious life. See id. at 222 (free exercise clause recognizes value of religious training, teaching, and observance); Zorach v. Clauson, 343 U.S. 306, 313 (1952) ("[w]e are a religious people"); M. Howe, The Garden And ThE WILDERNESS 15-19 (1965) (religion clauses inspired in large part by evangelical principle meant to protect religions from worldly corruption). Concurrent with this commitment, however, the free exercise clause also protects the right of persons to be irreligious. See Torcaso v. Watkins, 367 U.S. 488 (1961) (state may not make belief in God condition of holding public office). Moreover, the establishment clause, U.S. Const. amend. I ("Congress shall make no law respecting an establishment of religion"), requires that statutes have a secular legislative purpose, have a principal or primary effect that neither advances nor inhibits religion, and not foster excessive entanglement with religion. Wolman v. Walter, 433 U.S. $229,235-36$ (1977).

4. E.g., Johnson v. Motor Vehicle Div., 197 Colo. 455, 593 P.2d 1363, cert. denied, 444 U.S. 885 (1979); Bureau of Motor Vehicles v. Pentecostal House of Prayer, Inc., 380 N.E.2d 1225 (Ind. 1978).

5. E.g., Wisconsin v. Yoder, 406 U.S. 205 (1972); State v. Kasuboski, 87 Wis. 2d 407, 275 N.W.2d 101 (Ct. App. 1978).

6. E.g., United States v. American Friends Serv. Comm., 419 U.S. 7 (1974) (withholding tax); Jaggard v. Commissioner, 582 F.2d 1189 (8th Cir. 1978), cert. denied, 440 U.S. 913 (1979) (self-employment tax).

7. E.g., Sherbert v. Verner, 374 U.S. 398 (1963); Thomas v. Review Bd., 391 N.E.2d 1127 (Ind. 1979), cert. granted, 444 U.S. 1070 (1980).

8. E.g., People v. Woody, 61 Cal. 2d 716, 394 P.2d 813, 40 Cal. Rptr. 69 (1964) (peyote); Town v. State ex rel. Reno, 377 So. $2 d 648$ (Fla. 1979), appeal dismissed and cert. denied, 101 S. Ct. 48 (1980) (marijuana).

9. E.g., Brown v. Dade Christian Schools, Inc., 556 F.2d 310 (5th Cir. 1977), cert. denied, 
labor laws, ${ }^{10}$ snake-handling prohibitions, ${ }^{11}$ and bigamy proscriptions. ${ }^{12}$ Serious judicial consideration of such claims is a relatively recent, ${ }^{13}$ and still controversial, ${ }^{14}$ element of First Amendment doctrine. The approach adopted by the courts has been illconceived and unconvincing. ${ }^{15}$

\section{A. Evolution of Exemption Doctrine}

Debate over the framers' intent as to the scope of the free exercise clause has been vigorous but inconclusive. ${ }^{16}$ The most accurate statement may be that the framers did not contemplate the problems that would arise from the combination of increasing government activity and growing religious diversity. ${ }^{17}$

In its earliest opinion on the exemption issue, the Supreme

434 U.S. 1063 (1978) (claim that private school's racial discrimination on religious grounds was protected from civil rights action); Bob Jones Univ. v. Johnson, 396 F. Supp. 597 (D.S.C. 1974), aff'd, 529 F.2d 514 (4th Cir. 1975) (similar claim against federal funding cutoff).

10. E.g., Catholic Bishop v. NLRB, 559 F.2d 1112 (7th Cir. 1977), aff'd on other grounds, 440 U.S. 490 (1979) (free exercise challenge to NLRB jurisdiction over lay teachers in parochial schools).

11. E.g., State v. Massey, 229 N.C. 734, 51 S.E.2d 179, appeal dismissed sub nom. Bunn v. North Carolina, 336 U.S. 942 (1949) (denying religious defense to municipal ordinance prohibiting handling of venomous and poisonous reptiles as to endanger public health, safety, and welfare); State ex rel. Swann v. Pack, 527 S.W.2d 99 (Tenn. 1975), cert. denied, 424 U.S. 954 (1976) (upholding, and justifying as abatement of public nuisance, injunction against snake handling by members of religious group).

12. E.g., Cleveland v. United States, 329 U.S. 14 (1946) (transportation of plural wives as violation of Mann Act); Reynolds v. United States, 98 U.S. 145 (1878) (denying religious defense to federal law forbidding bigamy in United States territories).

13. See Pfeffer, The Supremayy of Free Exercise, 61 Geo. L.J. 1115, 1139 (1973) (identifying Sherbert v. Verner, 374 U.S. 398 (1963), as turning point in doctrinal development).

14. See, e.g., M. Malbin, Religion and Politics $39-40$ (1978) (criticizing religion-based exemptions); Kurland, The Irrelevance of the Constitution: The Religion Clauses of the First Amendment and the Supreme Court, 24 VILL. L. Rev. 3, 16-17 (1978) (same).

15. Cf. Clark, Guidelines for the Free Exercise Clause, 83 HARv. L. REv. 327, 329-30 (1969) (present doctrine not predictable or coherent); Kurland, The Supreme Court, Compulsory Education, and the First Amendment's Religion Clauses, 75 W. VA. L. REv. 213, 244 (1973) (Supreme Court has not established a "doctrinal base").

16. See Summers, The Sources and Limits of Religious Freedom, 41 ILL. L. REv. 53, 55-58 (1946) (historical argument inconclusive and misleading). Compare R. MoRgan, THE SuPREME CouRT AND Religion 23 (1972) ("freedom of conscience" did not mean that government could not force persons to do things that offended them) with Freeman, $A$ Remonstration for Conscience, 106 U. PA. L. Rev. 806, 808-13 (1958) (protection of actions based upon conscience included in motivation for religion clauses). The framers themselves may not have had a common understanding. See M. MALBin, supra note 14, at 19-37 (Madison likely believed in religion-based exemptions, but others did not share his views).

17. See Gianella, Religious Liberty, Non-Establishment, and Doctrinal Development (pt. 1), 80 HARv. L. REv. 1381, $1387-90$ (1967) (unlikely that authors of First Amendment appreciated inner tension between the two religion clauses); Marcus, The Forum of Conscience: Applying Standards Under the Free Exercise Clause, 1973 Duke L.J. 1217, 1232-33 (specific problems that now arise could not have been imagined by founding fathers). 
Court declared that only religious beliefs, not religiously-motivated actions, were constitutionally protected. ${ }^{18}$ This belief-action distinction implicitly precluded the possibility of religion-based exemptions. ${ }^{19}$ The Court eroded the belief-action distinction in the $1940 \mathrm{~s}$ in a series of decisions that upheld rights of religious expression. ${ }^{20}$ Those cases, however, rested heavily upon free speech considerations $^{21}$ and did not authorize religion-based exemptions. ${ }^{22}$

18. Reynolds v. United States, 98 U.S. 145, 164 (1878) (upholding polygamy conviction of Utah Mormon). Commentators have found little intelligible content in the belief-action distinction itself. See, e.g., L. Tribe, AMERICAN Constrtutronal LAW \& 14-8, at 838 (1978) (distinction more apparent than real); Marcus, supra note 17, at 1233-35 (carried to logical conclusion, distinction is ludicrous). Some commentators, however, have identified it with a doctrine that would deny free exercise protection against laws that have valid secular objectives. See R. Morgan, supra note 16, at 41 (equating belief-action distinction with secular regulation rule); L. TRIBE, supra, § 14-8, at 837 (belief-action distinction can be understood most clearly in terms of secular purpose requirement); cf. Gianella, supra note 17, at 1387 (Reynolds court itself would probably not have permitted interference with certain actions).

19. See Reynolds v. United States, 98 U.S. 145, 166-67 (1878) (exemptions would "in effect ... permit every citizen to become a law unto himself"); $c f$. Hamilton v. Regents, 293 U.S. 245, 265-68 (1934) (Cardozo, J., concurring) (religious judgment cannot be "exalted above the powers and the compulsion of the agencies of government"). The logic of either the belief-action distinction or the secular-purpose formula precludes constitutional protection from otherwise constitutional laws, and thereby forecloses the possibility of religionbased exemptions. See Minersville School Dist. v. Gobitis, 310 U.S. 586, 594 (1940) (“[c]onscientious scruples ... [do not relieve] the individual from obedience to a general law not aimed at the promotion or restriction of religious beliefs").

20. E.g., Murdock v. Pennsylvania, 319 U.S. 105, 109 (1943) (distribution of religious tracts is protected activity); Cantwell v. Connecticut, 310 U.S. 296, 303-04 (1940) (First Amendment embraces both freedom to believe and freedom to act, though latter cannot be absolute). Those decisions also eroded the closely related secular-purpose rule. See West Va. State Bd. of Educ. v. Barnette, 319 U.S. 624, 640 (1943) (permissible goals may not be accomplished by impermissible means); Cantwell v. Connecticut, 310 U.S. 296, 306-07 (1940) (same).

The belief-action distinction, though no longer an absolute guide in free exercise cases, remains an important benchmark. See, e.g., McDaniel v. Paty, 435 U.S. 618, 626-27 (1978) (because provision barring clergymen from serving as delegates to state constitutional convention was aimed at act, absolute prohibition against infringement on "freedom to believe" not engaged); State ex rel. Swann v. Pack, 527 S.W.2d 99, 108-11 (Tenn. 1975), cert. denied, 424 U.S. 954 (1976) (compelling state interest may justify regulation of action or conduct).

21. E.g., West Va. State Bd. of Educ. v. Barnette, 319 U.S. 624 (1943) (invalidating compulsory flag salute); Martin v. Struthers, 319 U.S. 141 (1943) (invalidating ban on door-to-door distribution of circulars); see M. HowE, supra note 3, at 109 ("[i]n nearly every opinion ... Court ... [insisted] that whatever protection it was giving to religious speech or conscience it would also give to non-religious speech or conviction"); Pfeffer, supra note 13 , at 1130 (whenever free exercise claim stood alone, it was unsuccessful).

22. See, e.g., West Va. State Bd. of Educ. v. Barnette, 319 U.S. 624, 635-36 (1943) (validity of compulsory flag salute must be framed in terms of overall constitutionality rather than religion-based exemption); Murdock v. Pennsylvania, 319 U.S. 105, 108-09 (1943) (tax on distribution of religious literature on its face violation of First Amendment). Though some of the cases spoke of granting exemptions, they actually held that the challenged statutes were facially overbroad insofar as the statutes reached religious activities. See, e.g., Follett v. Town of McCormick, 321 U.S. 573, 575-78 (1944) (distributors of religious literature cannot be required to obtain bookseller's license). Such cases therefore represent a general application of the free exercise clause. See note 1 supra. 
The Court took a decisive turn in 1963 in Sherbert $v$. Verner. ${ }^{23}$ Drawing heavily from other types of First Amendment cases, ${ }^{24}$ the Court held that only a compelling state interest could justify imposing a burden upon the exercise of religion ${ }^{25}$ and that the state bore the burden of demonstrating that no less restrictive regulation could achieve its aims. ${ }^{26}$ Nine years later, in Wisconsin $v$. Yoder, ${ }^{27}$ the Court reiterated that the Constitution sometimes requires religionbased exemptions, ${ }^{28}$ and it undertook a thorough analysis, weighing both the religious and state interests involved to determine which should prevail. ${ }^{29}$

The present state of exemption doctrine is unclear. Neither Sherbert nor Yoder involved a pure case of exemption from an otherwise constitutional law. ${ }^{30}$ Moreover, the courts have not been consistent in outlining the structure of their balancing test. ${ }^{31}$

23. 374 U.S. 398 (1963) (Seventh-Day Adventist awarded unemployment insurance benefits denied her because she refused to work on Saturdays).

24. For its compelling state interest requirement, the Sherbert court cited NAACP v. Button, 37 I U.S. 415 (1963), and Thomas v. Collins, 323 U.S. 516 (1945), both free speech cases. See Sherbert v. Verner, 374 U.S. 398, 403, 406 (1963). For the less restrictive alternative test, the Court cited Shelton v. Tucker, 364 U.S. 479 (1960) (freedom of association); Talley v. California, 362 U.S. 60 (1960) (freedom of speech); Martin v. Struthers, 319 U.S. 141 (1943) (freedom of speech and press); and Schneider v. New Jersey, 308 U.S. 147 (1939) (same). See Sherbert v. Verner, 374 U.S. 398, 407-08 (1963). Martin and Schneider involved the distribution of religious literature and therefore had free exercise overtones.

25. 374 U.S. at 403 .

26. Id. at 407 .

27. 406 U.S. 205 (1972) (excusing Old Order Amish from compulsory education above the eighth grade).

28. Id. at 220-21. The Court had never adequately reconciled the earlier Sherbert decision with Braunfeld v. Brown, 366 U.S. 599 (1961) (denying Orthodox Jew exemption from Sunday-closing laws), and it seemed something of an aberration. See Ely, Lcgislative and Administrative Motivation in Constitutional Law, 79 YALE L.J. 1205, 1322 (1970) (arguing that Sherbert should not be followed); Pfeffer, supra note 13, at 1140 (until Yoder, it appeared that Sherbert might have been isolated opinion).

29. 406 U.S. at $215-34$.

30. Sherbert was complicated by South Carolina's decision that leaving a job for religious reasons was not "good cause," 374 U.S. at 401, and by the state's express solicitude for Sunday worshippers, $i d$. at 406 , both of which may have been contrary to the general application of the free exercise clause. See P. Kauper, Religion and THE Constitution 42 (1964) (Sherbert could have been decided on discrimination grounds.) Yoder, in turn, relied in part upon the right of parents to play an important role in determining the education of their children. See 406 U.S. at 213, 232-34. But cf. McDaniel v. Paty, 435 U.S. 618, 628 $\mathrm{n} .8$ (1978) (approving balancing process employed by lower courts in exemption cases).

The Supreme Court may clarify its religion-based exemptions doctrine when it decides Thomas v. Review Bd., 391 N.E.2d 1127 (Ind. 1979), cert. granted, 444 U.S. 1070 (1980) (denying unemployment insurance benefits to worker who quit job because of ostensible religious scruples).

31. Some cases apply a two-tiered, modified balancing test, in which a sufficient degree of religious interest triggers a burden on the state to demonstrate a compelling state interest and the lack of a less restrictive alternative; if the burden is met, the statute is valid. See, 
Nevertheless, a rough composite test has emerged..$^{32}$ A court faced with a claim for a religion-based exemption from a government regulation will first consider the sincerity of the religious claim being advanced ${ }^{33}$ and the degree to which the challenged regulation interferes with vital religious practice or belief. ${ }^{34}$ It will then weigh, on the other side of the balance, the importance of the secular value underlying the rule, ${ }^{35}$ the impact of an exemption upon the regulatory scheme,$^{36}$ and the availability of a less restrictive alternative. ${ }^{37}$ The result of this balancing process determines whether or not the court will grant an exemption.

\section{B. Failures in Theory and Practice}

The current exemption test is fundamentally flawed. As with any ad hoc balancing test, ${ }^{38}$ it leads to inconsistent and unprincipled

e.g., Sherbert v. Verner, 374 U.S. 398, 406 (1963); Johnson v. Motor Vehicle Div., 593 P.2d 1363, 1365 (Colo.), cert. denied, 444 U.S. 885 (1979). Other cases apply a "true" balancing test that, although it also requires a threshold religious interest as a trigger, undertakes a detailed consideration of the relative weights of the religious and state interests. See, e.g., Wisconsin v. Yoder, 406 U.S. 205, 215 (1972); People v. Woody, 61 Cal. 2d 716, 725, 394 P.2d 813, 820, 40 Cal. Rptr. 69, 76 (1964).

32. For a careful discussion of a "thoroughgoing balancing test," see Gianella, supra note 17.

33. See, e.g., United States v. Kuch, 288 F. Supp. 439, 445 (D.D.C. 1968); In re Grady, 61 Cal. 2d 887, 888, 394 P.2d 728, 729, 39 Cal. Rptr. 912, 913 (1964); Dobkin v. District of Columbia, 194 A.2d 657, 659 (D.C. Ct. App. 1963). The parties often stipulate the sincerity of the religious proponent. See, e.g., Varga v. United States, 467 F. Supp. 1113, 1115 (D. Md. 1979), affd, 618 F.2d 106 (4th Cir. 1980); Johnson v. Motor Vehicle Div., 593 P.2d 1363, 1364 (Colo.), cert. denied, 444 U.S. 885 (1979).

34. This involves an examination of whether the relevant belief is "religious," see note 45 infra (discussing judicial definitions of religion), and how the state is impinging upon it, st't, $k$.g. . Wisconsin v. Yoder, 406 U.S. 205, 218 (1972); Bureau of Motor Vehicles v. Pentecostal House of Prayer, 380 N.E.2d 1225, 1228 (Ind. 1978). It may also involve inquiries into such matters as whether the relevant belief is "central" to the religious faith, whether the state infringes it directly or indirectly, and whether the religion would excuse noncompliance. Set pp. 360-61 infra (discussing such inquiries).

35. See, e.g., Wisconsin v. Yoder, 406 U.S. 205, $221-29$ (1972); State ex rel. Swann v. Pack, 527 S.W.2d 99, 113 (Tenn. 1975), cert. denied, 424 U.S. 954 (1976).

36. Ste, e.g., Johnson v. Motor Vehicle Div., 593 P.2d 1363, 1365 (Colo.), cert. denied, 444 U.S. 885 (1979); In re Jenison, 267 Minn. 136, 137, 125 N.W.2d 588, 589 (1963).

37. See, e.g., Sherbert v. Verner, 374 U.S. 398, 407 (1963); Bureau of Motor Vehicles v. Pentecostal House of Prayer, Inc., 380 N.E.2d 1225, 1229 (Ind. 1978). Although commentators have shown particular favor to the less restrictive alternative test, see, e.g., L. TRIBE, supra note 18, \$ 14-10; Merel, The Protection of Individual Choice: A Consistent Understanding of Religion Under the First Amendment, 45 U. CHI. L. REv. 805, 817-21 (1978), courts have often been quick to dismiss proposed alternative burdens, see, e.g., Johnson v. Motor Vehicle Div., 593 P.2d 1363, 1365 (Colo.), cert. denied, 444 U.S. 885 (1979) (other forms of identification as substitute for picture on driver's license); State ex rel. Swann v. Pack, 527 S.W.2d 99, 114 (Tenn. 1975), cert. denied, 424 U.S. 954 (1976) (restrictions on snake handling as alternative to prohibition).

38. Commentators distinguish between ad hoc balancing-the case-by-case weighing of conflicting interests-and definitional balancing-the formulation of general rules from a 
decisions. ${ }^{39}$ That problem is particularly acute in this area because the contexts in which claims for exemptions arise are so varied. ${ }^{40}$ But the present test's reliance upon ad hoc balancing is only one element of a more general failure in theory and practice. ${ }^{41}$

\section{Conceptual Defects}

Religious-exemption doctrine, borrowed as it is from other sources of constitutional law, does not address the distinctive features of the exemption context. The doctrine suffers from three conceptual defects.

First, courts have failed to develop an independent justification for religion-based exemptions. Exemption doctrine has therefore been unable to provide a principled answer to objections that religion-based exemptions contradict the rule of law, ${ }^{42}$ violate general notions of equal treatment, ${ }^{43}$ and violate the establishment clause. ${ }^{44}$ This failure has also prevented courts from defining, in a

weighing of competing principles. See Nimmer, The Right to Speak from Times to Time: First Amendment Theory Applied to Libel and Misapplied to Privacy, 56 CALIF. L. Rev. 935, 939-45 (1968); $c f$. Marcus, supra note 17, at 1242 (concluding that present free exercise doctrine is essentially ad hoc, though Court has defined certain state interests as not compelling in any case).

39. See Clark, supra note 15, at 330 (free exercise and other balancing tests are formless and unprincipled, give little guidance to potential litigants, and can be overly deferential to legislative judgment); Marcus, supra note 17, at 1240-41 (same).

40. See pp. 351-52 supra (examples of exemption claims); cf. Clark, supra note 15, at 330 (because particular interests involved in free exercise cases vary, uncertainties of ad hoc test are especially great).

41. Courts could add some certainty to exemption doctrine by making greater use of definitional balancing--distilling the balancing test into specific guidelines. $C f$. Clark, supra note 15 (suggesting guidelines for free exercise adjudication). But such definitional balancing, unaccompanied by a basic reconceptualization, would still suffer from many of the same failures as does ad hoc balancing. Cf. DuVal, Free Communication of Ideas and the Quest for Truth: Toward a Teleological Approach to First Amendment Adjudication, 41 GEo. WASH. L. REv., 161, 180 (1972) (neither ad hoc nor definitional balancing in free speech context adequately focuses upon guarantee's purpose).

42. See Minersville School Dist. v. Gobitis, 310 U.S. 586, $594-95$ (1940) (conscientious beliefs should not relieve individuals of duty to obey valid laws); Kurland, supra note 14, at 16 (religion-based exemptions give protected persons "license to violate the laws with impunity").

43. See F. Hayek, The Constitution of Liberty 153-56 (1960) (only abstract rules laid down irrespective of their particular application allow persons to be free and not subject to will of others); of. Clark, supra note 15, at 345, 348 (important factor in adjudicating exemption claims should be whether state can impose alternative burdens that retain objective equality).

44. See Ely, supra note 28, at 1313-14 (combination of religion clauses requires that government not go out of its way in any context to favor or disfavor particular religion or religion generally); Kurland, Of Church and State and the Supreme Court, 29 U. CHI. L. REv. I, 26, 96 (1961) (Constitution requires that government may not utilize religion as standard for action or inaction); Kurland, supra note 14, at 15-18 (Supreme Court has not reconciled religion-based exemptions with establishment clause); $c f$. Epperson v. Arkansas, 393 U.S. 


\section{Religious Exemptions}

consistent fashion, what constitutes a cognizable religious claim..$^{45}$

The courts' failure to develop a justification is compounded by the focus in present doctrine upon preventing injuries to conscience rather than enforcing claims of right; that is, the doctrine is more concerned with the possibility that the government will cause persons to suffer moral anguish than that it will violate their religious autonomy. ${ }^{46}$ Personal conscience is one of the least distinctive elements of religious life ${ }^{47}$ and opponents of religion-based exemptions can argue justifiably that such exemptions unfairly favor one type of conscience over others. ${ }^{48}$

97, 103-04 (1968) (First Amendment mandates neutrality among religions and between religion and nonreligion); R. Dworkin, Taking Rights Seriously, in TAKING Rights SERIOUSLY 184,201 (1977) (secular society cannot prefer religious to nonreligious morality). But see Wisconsin v. Yoder, 406 U.S. 205, 220-21 (1972) (establishment clause does not stand in way of exemptions vital to protection of values promoted by free exercise clause); Sherbert v. Verner, 374 U.S. 398, 409 (1963) (exemption may promote neutrality in face of religious differences).

A related objection is that allowing religion-based exemptions forces courts to become impermissibly enmeshed in the task of defining what is religious. See Weiss, Privilege, Posture, and Protection: "Religion" in the Law, 73 YaLE L.J. 593, 622 (1964).

45. Courts have abandoned their traditional, purely theistic view of religion. Compare Davis v. Beason, 133 U.S. 333, 342 (1890) (defining religion as "relations to [one's] Creator, and ... obligations [those relations] impose of reverence for his being and character, and of obedience to his will") with Torcaso v. Watkins, 367 U.S. 488,495 n.11 (196I) (recognizing many of world's religions are not theistic). Courts have also shown increased reluctance to limit the scope of what could be a religious belief. Compare Davis v. Beason, 133 U.S. $333,341-42$ (1890) (to call advocacy of polygamy "a tenet of religion is to offend the common sense of mankind") with United States v. Ballard, 322 U.S. 78, 86-87 (1944) (unusual religious beliefs are not less worthy of protection). Having rejected the old certainties, however, courts have been unable to find a stable medium ground between narrowminded limitations and no limitations at all, and they have sometimes resorted to a dubious search for doctrinal pedigree. See note 56 infra (describing and criticizing that inquiry).

46. See Johnson v. Robison, 415 U.S. 361, 385 (1974) (denial of veteran's benefits to conscientious objector who performed alternative service does not force oppressive choice upon him); Sherbert v. Verner, 374 U.S. 398, 404 (1963) (denial of unemployment benefits to Sabbatarian does force oppressive choice upon her); Clark, supra note 15, at 337 (framing one justification for free exercise clause in terms of avoiding pain to religious individuals); Gianella, supra note 17, at 1422-23 (courts regard "[g]overnment regulations that compel action contrary to conscience ... as more serious interferences with religious liberty than those which merely subject more or less passive religious dissenters to government action").

47. See M. Konvitz, Religious Liberty and Conscience 99 (1968) ("persons who avow religious beliefs . . . do not hold a monopoly on conscience"); M. WALZER, Conscientious $O b$ jection, in Obligations 120, 133 (1970) (conscience of religious persons no more real than that of other persons).

48. Sit, e.g., Kurland, supra note 15, at 237-41; Weiss, supra note 44, at 622-23.

The First Amendment could be read to include a general "right of conscience." Gillette v. United States, 401 U.S. 437, 465-66 (1971) (Douglas, J., dissenting); M. Konvitz, supra note 47 , at 104-06. In some contexts, such a right has already been recognized. See Wooley v. Maynard, 430 U.S. 705 (1977) (state may not compel drivers to display official motto on their license plates). Nevertheless, a broadly defined general "right of conscience" would require a basic rethinking of democratic theory, $c f$. p. 362 infra (law takes precedence over individual desire), and a commitment to a significantly more liberatarian form of govern- 
The second conceptual flaw of existing doctrine is that it erroneously treats consideration of an exemption claim as an assessment of the constitutionality of a statute. Ordinarily, courts should review laws to correct legislative mistake or abuse, ${ }^{49}$ applying strict scrutiny only if there is particular reason to suspect the legislative product. $^{50}$ In such cases, a court may appropriately undertake a substantive evaluation of the law in order to determine whether the legislative judgment was improper. ${ }^{51}$

The nature of the adjudication is fundamentally different in the exemption context. ${ }^{52}$ Because claims for exemption arise out of a law's incidental conflict with externally derived norms, not out of any legislative mistake or abuse, ${ }^{53}$ a legislature cannot insure that

ment, $c f$. R. Nozick, ANARchy, State, AND Utopia ix (1974) (any state with more than very narrow functions violates persons' rights not to be forced to do certain things), while a more narrowly defined right would leave many religious claims unprotected.

49. See Linde, Due Process of Lawmaking, 55 NEB. L. REv. 197, 206-07 (1976) (constitutional rules must be framed so that conscientious government could in theory comply with them).

This account of judicial review makes no claim regarding precisely to what level of diligence or good faith courts do or should hold legislatures; it merely claims that the process implies some such standards. For example, though legislatures can perhaps all too easily adhere to the rule of conduct inherent in the Supreme Court's racial discrimination doctrine, see Washington v. Davis, 426 U.S. 229, 240 (1976) (equal protection claim requires proof of racially discriminatory purpose), they could also adhere to the rules of conduct implicit in tests proposed by dissenting commentators, see, e.g., Perry, The Disproportionate Impact Theory of Racial Discrimination, 125 U. PA. L. REV. 540, 559 (1977) (proposing that disproportionate racial impact test be applied in contexts in which there is causal connection with historical pattern of discrimination).

50. See United States v. Carolene Products Co., 304 U.S. 144, 152 n.4 (1938) (strict scrutiny should be applied when legislation appears on its face to violate constitutional prohibition, and might apply when legislation restricts political process, or when it is directed at particular minorities); $c f$. J. Ely, Democracy and Distrust I02-03 (1980) (judicial review necessary when process of substantive decisionmaking cannot be trusted); L. TRIBE, supra note 18 , \& $11-4$, at 575 (strict scrutiny applied when protected values seem politically fragile).

51. See Landmark Communications, Inc. v. Virginia, 435 U.S. 829,843 (1978) ("[d]eference to a legislative finding cannot limit judicial inquiry when First Amendment rights are at stake"); Moore v. City of East Cleveland, 431 U.S. 494, 499 (1977) (usual judicial deference inappropriate when legislature intrudes upon rights of family; court must then carefully examine importance of competing interests); Tribe, The Supreme Court, 1972 TermForeword: Toward a Model of Roles in the Due Process of Life and Law, 87 HARv. L. REv. 1, 30-32 (1973) (judicial "second-guessing" of legislative judgment in abortion decisions neccessary because of factors prejudicing legislative process).

52. Commentators attempting to develop general standards of judicial review have noted the anomalous treatment of claims for religion-based exemptions. See Eisenberg, Disproportionate Impact and Illicit Motive: Theories of Constitutional Adjudication, 52 N.Y.U. L. REv. 36 , 165-66 (1977) (contrasting impact analysis in free exercise cases with motive requirement in equal protection cases); Ely, supra note 28, at 1315-17 (free exercise cases should not be determined on basis of impact per se).

53. This is true by hypothesis. See p. $\mathbf{3 5 0}$ supra (discussing nature of exemption claims). Not all claims for exemptions are in fact against laws that are otherwise clearly constitutional. See p. 354 supra (discussing Sherbert and Yoder). 


\section{Religious Exemptions}

its laws will not be susceptible to claims of interference in the exercise of religion. ${ }^{54}$ Therefore, courts are placed in the position of scrutinizing possibly every enactment to determine whether it is justified by a compelling state interest. ${ }^{55}$

The third conceptual defect of exemption doctrine is its excessive intrusion into religious autonomy. ${ }^{56}$ The intrusion occurs in

54. Even when a legislature includes specific religious exemptions in a statute, claims outside the scope of the legislative provision are likely to be made. See, e.g., Gillette v. United States, 401 U.S. 437 (1971) (claiming exemption from draft based upon religious objection to particular war rather than all war); Kennedy v. Bureau of Narcotics \& Dangerous Drugs, 459 F.2d 415 (9th Cir. 1972), cert. denied, 409 U.S. 1115 (1973) (claiming exemption from narcotics statute despite failure to be member of religious group qualifying for exemption under regulations).

55. See Ely, supra note 28, at 1316 (most government actions affect some religions, and it is impossible that all such actions are unconstitutional); Weiss \& Wizner, Pot, Prayer, Politics, and Privacy: The Right to Cut Your Own Throat in Your Owm Way, 54 Iowa L. Rev. 709, $716-17$ (1969) (assessing amount of damage that may result from unlawful act is not proper judicial function).

Some commentators urge that in evaluating whether a state interest is compelling, courts should only measure the incremental benefit of applying the law to those who may be eligible for an exemption. See L. TRIBE, supra note 18, \$ 14-10, at 855; Clark, supra note 15, at 331. This method makes some sense when society's only interest in enforcing a legal rule in individual cases is that the aggregate result furthers some given goal. One example may be the rule that persons acquire a social security number. See Stevens v. Berger, 428 F. Supp. 896 (E.D.N.Y. 1977) (allowing exemption and arguing that impact upon aggregate benefit of rule would be minimal). In the case of a great many, if not most, laws, however, society is concerned with individual enforcement as well as aggregate effect, so that measuring incremental benefit is inextricably tied to measuring general compellingness. See, e.g., Wisconsin v. Yoder, 406 U.S. 205, $239-40$ (1972) (White, J., concurring) (discussing benefits to children of compulsory education); J.F.K. Memorial Hosp. v. Heston, 58 N.J. 576, 580-84, 279 A.2d 670, 672-74 (1971) (asserting state interest in preserving individual lives); $c f$. R. Dworkin, Hard Cases, in Taking Rights Seriously 81, 82, 91 (1977) (distinguishing individuated and nonindividuated political aims). Even when the incremental benefit of a law seems easily quantifiable in some respects, other factors may be at work. The goal of a progressive tax system, for example, is not only to raise revenue, but also to equalize incomes. See Blum \& Kalven, The Uneasy Case for Progressive Taxation, 19 U. CHI. L. REv. 417, 519-20 (1952).

56. See Weiss, supra note 44 , at 622 (assessing religious beliefs in itself intrudes into religious freedom).

The use of intrusive and improper tests has extended into the process of determining whether particular beliefs of religious groups are themselves religious. Courts have been unable to define adequately what constitutes a religious belief. See note 45 supra; $c f$. Wisconsin v. Yoder, 406 U.S. 205, 215-16 (1972) (distinguishing religious from personal and philosophical beliefs, without attempting to define either). Courts have therefore resorted to dubious tests of doctrinal pedigree. See, e.g., id. at 216-18 (concluding Amish objection to compulsory education was religious because shared by organized group, derived from scripture, and long held); State v. Kasuboski, 87 Wis. 2d 407, 414-18, 275 N.W.2d 101, 104-06 (Ct. App. 1978) (applying Yoder test to conclude that auxiliary church's objection to education in local public school was personal and philosophical rather than religious). Such tests fail to recognize that the right of a religion to change or interpret its doctrine is itself protected by the First Amendment, $c f$. Presbyterian Church in the United States v. Mary Elizabeth Blue Hull Memorial Presbyterian Church, 393 U.S. 440, 451 (1969) (courts may not use "departure-from-doctrine" rule in resolving church property disputes), and that many religions ascribe to individuals the right to interpret religious doctrine, see note 
two respects: in weighing the religious interests at stake and in focusing upon injuries to conscience. Though any exemptions scheme must determine when religious interests are at stake, ${ }^{57}$ current doctrine goes beyond such threshold tests, differentiating among religious claims so that a court can weigh them against government interests. ${ }^{58}$ Courts have relied upon a distinction between activities central to a religion's way of life and those that are incidental parts of religious belief..$^{59}$ This inquiry into centrality is beyond the practical ${ }^{60}$ and institutional ${ }^{61}$ competence of courts. Moreover, the very notion of centrality is so vague that it can obscure the use of even less defensible distinctions. ${ }^{62}$

In addition, the doctrine's focus upon preventing injuries to conscience rather than enforcing claims of right engenders a number of pernicious distinctions. Courts have held, for example, that government may impose indirect burdens upon the exercise of reli-

115 infra (citing examples). Inquiries into doctrinal pedigree favor well-documented and familiar religious faiths without justifying how that preference is anything more than gratuitous.

57. But $c f$. note 48 supra (discussing possibility of recognizing general "right of conscience").

58. See pp. 354-55 supra (describing balancing test). The need to differentiate among religious claims is most evident in cases applying a "true," rather than a modified, balancing test, since, in such cases, courts must weigh the importance of both the religious and state interests at stake. See note 31 supra (discussing two forms of test).

59. See, e.g., Wisconsin v. Yoder, 406 U.S. 205, 218-19 (1972) (compulsory education law caused "grave interference with important Amish religious tenets"); People v. Woody, 61 Cal. 2d 716, 725, 394 P.2d 813, 820, 40 Cal. Rptr. 69, 76 (1964) (peyote was "sine qua non of defendants' faith"); cf. Leary v. United States, 383 F.2d 851, 861 (5th Cir. 1967), rev'd on other grounds, 395 U.S. 6 (1969) (distinguishing Woody on centrality issue).

60. See M. Konvitz, supra note 47, at 77-79 (discovering essence of particular religion difficult even for theologians; religions have survived loss of even apparently fundamental features). Among the dangers inherent in the "centrality" inquiry is the natural tendency to use familiar criteria taken from general experience. See, e.g., Brown v. Dade Christian Schools, Inc., 556 F.2d 310, 321 (5th Cir. 1977), cert. denied, 434 U.S. 1063 (1978) (Goldberg, J., concurring) (importance of belief in racial segregation minimized because disobedience would not endanger salvation); People v. Woody, 61 Cal. 2d 716, 720-21, 394 P.2d 813, 817-18, 40 Cal. Rptr. 69, 73-74 (1964) (comparing peyote cult's beliefs and practices to those of more familiar groups).

61. See M. Konvitz, supra note 47 , at 79 (judicial efforts to find essence of particular religion equivalent to defining what one may label orthodox or heretical); $c f$. Presbyterian Church in the United States v. Mary Elizabeth Blue Hull Memorial Presbyterian Church, 393 U.S. 440, 450 (1969) (civil courts may not judge relative importance of doctrines of religious group); Watson v. Jones, 80 U.S. (13 Wall.) 679, 728 (1871) ("[t]he law knows no heresy").

62. For example, the centrality of an activity may be defined in terms of its sacramental significance, see People v. Woody, 61 Cal. 2d 716, 721-22, 725, 394 P.2d 813, 817-18, 820, 40 Cal. Rptr. $69,73-74,76$ (1964), thus excluding religions that believe in communion with God through deeds rather than sacraments, see, e.g., A. Heschel, God in Search of MaN 281-92 (1955) (discussing role of "mitzvot" in Judaism); The Laws of Manu 30-31 (G. Bühler trans. 1886) (discussing "dharma" in Hinduism). 


\section{Religious Exemptions}

gion even when it cannot directly regulate religion-related activity, ${ }^{\text {b3 }}$ that it may compel violation of religious doctrine if the religion does not blame the believer for such compelled violations, ${ }^{64}$ and that it may coerce compliance with a law even if it could not punish noncompliance. ${ }^{65}$

\section{Practical Defects}

The structure of present doctrine allows courts to be inconsistent and illiberal. Though courts have granted a number of exemptions, ${ }^{66}$ they have also made dubious findings that a state has a compelling interest in requiring, for example, driver's license applicants to be photographed, ${ }^{67}$ persons willing to pay annual taxes to participate in the withholding tax system, ${ }^{68}$ and adult hospital patients to receive blood transfusions. ${ }^{69}$ The adjudicative process, moreover, has often involved impermissible judgments as to the

63. See, e.g., Johnson v. Robison, 415 U.S. 361, 385 (1974) (denial of veteran's benefits to conscientious objector who performed alternative service only imposes at most indirect burden on him); Braunfeld v. Brown, 366 U.S. 599, 605-06 (1961) (Sunday-closing laws only an indirect burden on Orthodox Jew who closes his store on Saturday). But see Sherbert v. Verner, 374 U.S. 398, 417-18 (1963) (Stewart, J., concurring) (Sherbert eliminates distinction between direct and indirect burdens). "Indirect" burdens can be more punishing than "direct" ones. Compare Wisconsin v. Yoder, 406 U.S. 205, 208 (1972) (direct \$5 fine) with Braunfeld v. Brown, 366 U.S. 599, 601 (196I) (indirectly caused loss of business).

64. Ste, e.g., In re President of Georgetown College, Inc., 331 F.2d 1000, 1009 (D.C. Cir.), cert. denied, 377 U.S. 978 (1964) (compulsory blood transfusion); United States v. George, 239 F. Supp. 752, 753 (D. Conn. 1965) (same). Such a principle penalizes religions that have devised mechanisms for coping under repressive regimes, see note 116 infra (distinguishing different types of religious deference to state authority), and thereby allows the state to become one of those regimes.

65. See, e.g., J.F.K. Memorial Hospital v. Heston, 58 N.J. 576, 582, 279 A.2d 670, 673 (1971) (compulsory life-saving treatment); $c f$. Clark, supra note 15, at 347, 353 (arguing criminal penalties may be inappropriate if compliance can be coerced).

66. Set Shetreet, Exemptions and Privileges on Grounds of Religion and Conscience, $62 \mathrm{Kr}$. L.J. 377, 377-91 (1974) (discussing both legislatively and judicially created exemptions).

67. Johnson v. Motor Vehicle Div., 197 Colo. 455, 593 P.2d 1363, cert. denied, 444 U.S. 885 (1979). The Johnson court was too uncritical in accepting the state's claim of compelling interest, and failed to take sufficient account of less restrictive alternatives. $C f$. Bureau of Motor Vehicles v. Pentecostal House of Prayer, Inc., 380 N.E.2d 1225 (Ind. 1978) (granting exemption).

68. United States v. American Friends Serv. Comm., 419 U.S. 7 (1974) (relying upon Anti-Injunction Act, I.R.C. $\$ 7421$ (a)). An incremental-benefits analysis, see note 55 supra, should have been dispositive in this case: whatever may be the total administrative advantage of the withholding tax system, the government would lose little if a small group of persons waited to pay taxes until the end of the year.

69. In re President of Georgetown College, Inc., 331 F.2d 1000 (D.C. Cir.), cert. denied, 377 U.S. 978 (1964); J.F.K. Memorial Hospital v. Heston, 58 N.J. 576, 279 A.2d 670 (1971). But see Estate of Brooks, 32 Ill. 2d 361, 373, 205 N.E.2d 435, 442 (1965) (forbidding compulsion in absence of clear and present danger to society). 
substantive worth of the beliefs being asserted; ${ }^{70}$ rather than balancing religious freedoms against state interests, many courts have in effect evaluated the desirability of the religious behaviour as an alternative to the state's general norm. ${ }^{71}$

\section{The Doctrine of Competing Authorities}

The free exercise clause reflects a commitment to the protection of religious liberty. ${ }^{72}$ But simply asserting this commitment does not explain how religion-based exemptions relate to either religious liberty or other basic values. That explanation can be found in approaching religion-based exemptions from a new direction: not as civil liberties in the ordinary sense, but rather as accommodations to competing sources of authority, an approach analogous to conflict of laws determinations. ${ }^{73}$ This doctrine of competing authorities could instill in courts a more self-confidently generous attitude toward religious claims.

\section{A. The Distinctive Nature of Religious Authority}

A basic premise of democratic theory is that when the government acts within the limits of its authority, it has the right to expect that its laws will take precedence over individual belief. ${ }^{74}$ Religion

70. See, e.g., Wisconsin v. Yoder, 406 U.S. 205, 222-27 (1972) (implied approval of Amish alternative life style); People v. Woody, 61 Cal. 2d 716, 394 P.2d 813, 40 Cal. Rptr. 69 (1964) (implied sympathy with Native American Church use of peyote as sacrament and object of worship).

71. See Burkholder, "The Law Knows No Heresy": Marginal Religious Movements and the Couts, in Religrous Movements in Contemporary America 27, 45 (I. Zaretsky \& M. Leone, eds. 1974). Such judgments themselves violate the First Amendment. See United States v. Ballard, 322 U.S. 78, 86-87 (1944) (courts may not inquire into truth or worth of religious beliefs).

72. See p. 351 supra (pure value of religious liberty nurtured in part by commitment to protection of religious life).

73. Commentators have often employed models and analogies to give meaning to the bare texts of First Amendment guarantees. See, e.g., A. MeIKLEJohn, FREE SPEech AND ITS Relation to Self-Government 22-27 (1948) (rationale and parameters of free speech clause can best be understood by analogy to rules governing "town meeting"); Stewart, "Or of the Press", 26 Hastings L.J. 631, 633-35 (1975) (free press guarantee can be understood as granting to press institutional rights analogous to that of branch of government).

Although some commentators on the religion clauses have used rhetoric that might support an analogy between religion-based exemptions and conflict of laws determinations, none has proposed explicit reference to the distinct legal doctrine of conflict of laws. See, e.g., Berger \& Neuhaus, Foreward to Church, State, and Public Policy (J. Mechling ed. 1978) (unpaginated) (jurisdictional claims of state and religion inevitably run into conflict); Wright, Book Review, 38 MinN. L. Rev. 87, 88 (1953) (courts assert that "state is free to punish violations of its law, while God punishes violations of His Law. It is left to the individual to decide which code he will obey.")

74. Wisconsin v. Yoder, 406 U.S. 205, 215-16 (1972) ("concept of ordered liberty precludes allowing every person to make his own standards on matters of conduct in which so- 
poses a special challenge to this theory. Although religion can be defined in many ways, ${ }^{75}$ that challenge is best understood by reference to three fundamental attributes generally associated with religion: it influences human behaviour; ${ }^{76}$ its adherents believe that its principles are authoritative; ${ }^{77}$ and the source of that authority is perceived to transcend both individual conscience ${ }^{78}$ and the state. ${ }^{79}$

These three attributes describe commonly recognized, Godbelieving, organized religions, but can extend as well to creeds that are nontheistic or noninstitutional. The attributes do not, however, apply to beliefs that are not purported to be compelled by a source beyond human judgment. Thus, Buddhism, a nontheistic religion, ${ }^{80}$ has the attributes of religion upon which this discussion focuses, as does a person's sense that God, or the cosmos, forces him

ciety as a whole has important interests"). The supremacy of law over individual desire plays an important role in the basic sources of liberal democratic theory. See, e.g., THE Federalist No. 2 (J. Jay); J. Locke, The Second Treatise of Civil Government, in Two TrEaTISES OF Crvil, GoverNMENT 99 129-31 (Hafner ed. 1947). Modern writers have expanded on this principle. See, e.g., J. Rawls, A THEORY of Justice 212, 368-71 (1971) (liberty of conscience limited by common interest in public order and security; conscientious refusal distinguished from politically aimed civil disobedience); P. SINGER, DEMOCRACY AND DISOBEDIENCE 59 (1973) (special reasons exist for obeying law in democracy); $c f$. G. PoGgI, The Development of The Modern State 101 (1978) (modern state legitimizes its rule by positive law enacted in accordance with constitutional rules).

75. See Clark, supra note 15 , at $339-40$ (distinguishing subject matter, sociological, and psychological definitions of religion).

76. See P. Berger, The Sacred Canopy 40-41 (1967) (religious ideation grounded in religious activity); 2 G. Van Der Leeuw, Religion in Essence and Manifestation 340 (J. Turner trans. 1963) (religious revelation leads persons into fixed course of activity); J. Wach, The Comparative Study of Religions 36-37 (1958) (religion issues in imperatives to action).

77. See notes 82-83 infra (religion much like civil government); W. CLARK, ThE PsYCHOLOGY of RELIGION 22-23 (1958) (religious person attempts to harmonize his life with divine will); Geertz, Religion: Anthropological Study, in 13 InTERnational Encyclopedia of THE Social ScIences 398, 406 (1968) (religion "relates a view of the ultimate nature of reality to a set of ideas of how man is well advised, even obligated, to live").

78. See P. BERGER, supra note 76, at 33-34 (religion legitimates social institutions by locating them within sacred and cosmic frame of reference that transcends both history and man); M. Buber, I AND Thou 123-68 (W. Kaufman trans. 1970) (religion is encounter with unconditional You); W. SMrth, The Meaning and End of Religion 173 (1964) ("The traditions evolve. Men's faith varies. God endures.")

79. See Berger \& Neuhaus, supra note 73 ("[a]uthentic religion ... must refer to a sovereignty that transcends the authority of the state"); Lekachman, The Perils of Power, in The Churches and The Public 5, 7 (Center for the Study of Democratic Institutions 1960) (because they justify their actions at least in part by appeals to divine inspiration, churches cannot accept temporal judgments on their spiritual mission).

Recognizing the distinct nature of religious belief does not, however, require abandoning more skeptical explanations for that belief. $C f$. W. James, The Varieties of Religrous EXPERIENCE 19-26 (1902) (psychological and physiological explanations of religious emotion do not exclude its study as distinct spiritual phenomenon).

80. See H. Von Glassenapp, Buddhism-A Non-Theistic Religion 48-53 (I. Schloegl trans. 1970) (Buddhism refers to an impersonal but fixed cosmic order). 
into a pattern of behaviour. On the other hand, a personal belief or organized creed that does not refer to a transcendent and authoritative source for that belief, but instead relies upon human reason or intuition, lacks these attributes.

Religious concerns can extend at least as wide as proper governmental concerns, ${ }^{81}$ and the two may therefore come into conflict. To the extent that a religious doctrine refers to a behavioral, authoritative, and transcendent system of commands, it is itself much like a civil government. ${ }^{82}$ Many religions have highly articulated legal codes ${ }^{83}$ and many postulate punishment for disobedience. ${ }^{84}$

The conceded preference of state authority over individual belief therefore cannot apply unproblematically. For government to reduce the role of religion to that of a system of belief, or even that of belief combined with a narrow range of actions, ${ }^{85}$ would be to ignore the behavioral, authoritative, and transcendent elements of religion. Such a course would not merely disadvantage a few sects or individuals, but would be a profoundly secularizing act. ${ }^{86}$ The alternative, for a society that values religion, is to read the free ex-

81. See, e.g., D. Manwaring, Render Unto Caesar 17 (1962) (Jehovah's Witnesses base all actions upon religious beliefs); P. WEISS, THE GoD WE SEEK 159 (1964) ("[e]verything can be looked at from a religious viewpoint"); Dorff, Judaism as a Religious Legal System, 29 Hastings L.J. 1331, 1333 (1978) (large segments of Jewish law cover subjects ordinarily considered secular).

82. See K. Barth, The Christian Community and the Civil Community, in AgaINST THE Stream 15, 18-19 (R. Smith ed. 1954) (Christian community, as well as civil community, lives and works within framework of law binding upon all members); H. KELSEN, GENERAL Theory of LAW AND STATE 20 (A. Wedberg trans. 1961) (religion closer to law than is morality). The analogy can be reversed. See, e.g., Bellah, Civil Religion in America, 96 DAEDALus 1 (1967) (American political ideology includes religious component).

83. See, e.g., J. Hostetler, Amish Society 58-62 (1963) (describing Amish "ordnung," or rules of church community); J. McKenzie, The Roman Catholic Church 25-26 (1969) (describing canon law); Dorff, supra note 81 (describing biblical and Talmudic system of law).

84. See, e.g., J. McKenzie, supra note 83 , at 156 (mortal sin separates man permanently from union with God); D. MANwaring, supra note 81, at 20 (Jehovah's Witnesses believe that a "Witness who backslides in any substantial matter of doctrine or conduct is doomed beyond hope of redemption").

85. See Dodge, The Free Exercise of Religion: A Sociological Approach, 67 Mrch. L. REv. 679, 697-99 (1969) (distinguishing between "belief," "therapy," "worship," and "ethical action" subsystems of religion; arguing that first two should be protected absolutely, third protected conditionally, and last unprotected); Weiss, supra note 44, at 608 (arguing that only religious belief and religious action that has no worldly consequences should be protected).

86. Cf. A. Greeley, Religion IN THE YeAR 2000, at 21 (1969) (meanings of secularization include relegation of religion to private sphere of human activity and lack of influence by religion on human behaviour); R. Mehl, The Socrology of Protestantism 61 (J. Farley trans. 1970) (at extreme of secularization, "religion no longer is considered as anything but a private affair, and the exercise of worship tends to be enclosed in very narrow limits"). 
ercise clause as, in part, granting limited recognition to the religious source of authority. ${ }^{87}$

\section{B. The Conflict of Laws Analogy}

A doctrine based upon recognition of competing authorities is best considered in the context of an authority-recognizing doctrine such as conflict of laws. Conflict of laws doctrine is consulted by the courts of an adjudicatory forum when a dispute involves the laws of other jurisdictions. ${ }^{88}$ Among the techniques used in conflict of laws are mechanical rules based upon the situs of crucial events, ${ }^{89}$ flexible inquiries into which territory has the most significant relationship to a set of events, ${ }^{90}$ and considerations of the functions of the divergent laws and the interests of the respective jurisdictions in having their laws govern the dispute. ${ }^{91}$

87. The notion of granting legal recognition to religious authority is not novel. Ecclesiastical courts had broad jurisdiction in medieval England. See S. Milsom, Historical Foundations of The Common Law 13-15 (1969); Jones, The Two Laws in England: The Later Middle Ages, 11 J. Church \& State 111 (1969). Today, various nations grant religious institutions particular powers. See, e.g., Rubinstein, Law and Religion in Israel, in Jewish Law IN ANCIENT AND Modern IsRael 190, 190-210 (H. Cohn ed. 1971) (describing Israeli religious courts); Taylor, Church and State in Scotland, 2 Jur. REv. 121 (1957) (describing established status of Church of Scotland). Even in the United States, religous institutions have virtually absolute autonomy over their internal governance. See Serbian E. Orthodox Diocese v. Milivojevich, 426 U.S. 696, 724-25 (1976); Watson v. Jones, 80 U.S. (13 Wall.) 679, 727 (1871). One recent work suggests that, in order to reduce the impersonality and bureaucratic oppressiveness of the modern "welfare state," public policy and constitutional doctrine should protect and foster the role of religious institutions, as well as the neighborhood, family, and voluntary associations, as "mediating structures." P. BERGER \& R. Neuhaus, To Empower Prople 1-3, 26-33 (1977).

The grant of recognition proposed in this Note differs from all of the above in two respects. First, the grant is not limited to a particular range of subject matter. Second, it does not extend to giving any adjudicative or administrative role to religious institutions beyond their claim to be transmitting or interpreting the dictates of the religious source of authority.

88. See G. Cheshire \& P. North, Cheshire's Private International Law 3 (10th ed. 1979) [hereinafter cited as Cheshire]; R. Leflar, AMERICAN Conflicts LAw $\S 2$, at 3 (3d ed. 1977); Restatement (SeCond) of Conflict of Laws $\$ 2$ (1971) [hereinafter cited as Restatement of Conflicts].

89. For example, the law applicable to a tort is often determined by the place where the injury occurred. See CheshIRE, supra note 88, at 259; Restatement of Conflicts, supra note $88, \$ 146$.

90. See, e.g., Cheshire, supra note 88, at 260-63 (arguable that foreign tort should be adjudged according to social environment in which it was committed); RestateMENT of Conflicts, supra note $88, \S 145$ (contacts relevant to determing which state has most significant relationship to alleged tort include place where injury occurred, place where conduct causing injury occurred, domicile of parties, and place where relationship between parties, if any, is centered).

91. See Seidelson, Interest Analysis: For Those Who Like It and Those Who Don't, 11 DuQ. L. REv. 283, 304-09 (1973) (courts should look to whether potentially interested states have substantial interest in issue presented). But of. R. LefLAR, supra note $88, \S 92$, at $185-86$ (discussing drawbacks of approach). 


\section{Establishing the Analogy}

A useful analogy can be drawn between religion-based exemptions and conflict of laws. ${ }^{92}$ Both are responses to claims that certain behaviour can be appropriately judged only by reference to an alien legal norm. The justification for religion-based exemptions arises from a gap in democratic theory: the state implicitly assumes that it is the only external legal authority that governs persons. Religious doctrine, however, has many of the characteristics of a legal system and can contradict secular law. The case for conflict of laws ${ }^{93}$ arises from a similar gap in conventional jurisprudential theory: systems of substantive law implicitly assume universal application. ${ }^{94}$ Each nation, however, has its own system of substantive law, and those systems can collide. ${ }^{95}$ When individuals have conformed their behaviour to or acquired rights under a foreign legal

92. The ambiguity of much of modern conflicts doctrine may make it appear to be a poor source of guidance for other fields of law. $C f$. von Mehren, Choice of Law and the Problem of Justice, LAw \& ConTEMP. ProB., Spring 1977, at 27, 27 (choice of law problems often seem intractable). But the analogy here is framed in such a way as to avoid most of these complexities. See note 100 infra (discussing territorial principle); note 102 infra (discussing third-party rule).

93. Conflict of laws principles are not logically inevitable; adjudicatory forums could always apply their own law to disputes before them or simply refuse to hear disputes involving a foreign element. See A. Dicey \& J. Morris, The Conflict of Laws 6 (9th ed. 1973) [hereinafter cited as Dicey]; Restatement of Conflicts, supra note 88 , $\$ 1$, Comment $c$. There are in fact commentators who advocate that forums regularly apply their own law. See, e.g., B. Currie, Notes on Methods and Objectives in the Conflict of Laws, in $\mathrm{SE}_{\mathrm{E} \text { - }}$ LECTEd ESSAYS ON THE CoNflict of Laws 177, 183-84 (1963) (even in cases involving foreign elements, courts should normally apply law of forum); Ehrenzweig, The Lex Fori-Basic Rule in the Conflict of Laws, 58 Mrch. L. Rev. 637, 637, 643-45 (1960) (application of forum law should be presumptive rule in conflict of laws). The existence of a forum preference school of conflict of laws actually strengthens the analogy between religion-based exemptions and conflict of laws by demonstrating that in both contexts there is a reasonable, if not ultimately compelling, argument for refusing to defer to the foreign source of authority. In this connection, it is significant that even the strongest advocates of forum preference never proposed that the forum's law always apply, see B. CuRRIE, supra, at 183-84 (forum law should apply unless forum has no interest in application of its policy); Ehrenzweig, supra, at 637, 643-45 (factors such as intentions of parties may justify exceptions to lex fori presumption), that most commentators have remained unconvinced by the forum preference school, see, e.g., CHESHIRE, supra note 88, at 3-4, 258-59 (strict lex fori rule would often lead to unjust results); R. LEFLAR, supra note $88, \S 90$, at 181-82 (mere forum preference is not valid reason for choice-of-law result), and that the leading members of the school have modified their own views in response to criticism, see A. EHRENZwEIG, Private International Law 62-65 (1967) (discussing both Currie and Ehrenzweig).

94. See B. Currie, Married Women's Contracts: A Study in Conflict-of-Laws Method, in SELECTED ESSAYS ON THE CONFLICT OF LAws 77, 82 (1963) (legislatures implicitly assume fully domestic context in enacting laws).

95. See B. CuRrIE, supra note 93, at 178-79 (world with single system of law would not require conflict of laws rules); Restatement of Conflicts, supra note $88, \S 1$, Comment a (ordinary court cases require reference only to law of forum); Von Mehren, supra note 92, at 28-30 ("justice" can be achieved fully only when legal unit coincides with social or economic unit within which problem arises). 
norm, blind application of domestic law is inadequate, and substantial deference to the foreign system of authority may be appropriate.

Both conflicts and exemption doctrine therefore require the state to undertake the unaccustomed task of fixing boundaries upon the application of its legal system. Conflict of laws rules are devised to prevent parochialism from frustrating the needs of the international system ${ }^{96}$ and to promote justice for individuals whose activities cross national borders. ${ }^{97}$ Similarly, a coherent and generous scheme of religion-based exemptions would prevent parochialism from unduly constricting the role of religion in society and would promote justice for individuals caught between competing authorities. Although the entire body of conflicts rules cannot be transplanted into the free exercise clause, ${ }^{98}$ the analogy, if pursued carefully and selectively, could provide the basic structure for a new exemption doctrine.

\section{Territoriality in the Religious Context}

An important distinction between conflict of laws and religionbased exemptions is that the former can rely upon the fact of physical territoriality. The analogy can be pursued, however, by devising standards for cognizable religious claims that in effect carve out a "territory" for religious concerns and articulate conditions

96. See Restatement of Conflicts, supra note 88, $\$ 6(2)(a)$ \& Comment d (regard for needs and policies of other states and for community of states furthers important goal of conflicts); Cheatham \& Maier, Private International Law and its Sources, 22 V AND. L. REv. 27, 95-97 (1968) (domestic law must be modified to meet needs of situations that confront it).

97. Cheshire, supra note 88 , at 258 (unjust to hold person responsible for what would be innocent act in place where it was committed); DicEy, supra note 93, at 6-7 (just determination of rights must sometimes involve reference to foreign law).

Conflicts rules have two other goals. The first, achieving uniformity of result in order to avoid forum shopping, s\&e R. LEFLAR, supra note $88, \S 103$, at 205 , is not relevant for purposes of the analogy. The second goal, furthering the policies of the states involved, is circular: those policies may include limits on the application of domestic law. See RestateMENT OF Conflicts, supra note $88, \$ 6(2)(\mathrm{b})$-(c) \& Comments e \& f; Von Mehren, Recent Trends in Choice-of-Law Methodology, 60 CoRnell L. Rev. 927, 931 (1975) ("local-law theory" of conflicts in itself provides no guidance as to when foreign law should be consulted).

98. Unreflective reference to the conflicts analogy may be particularly inappropriate when extended beyond the context of religion-based exemptions. For example, courts often must interpret and apply foreign law in resolving a dispute between two private parties, but the First Amendment forbids the courts from attempting to interpret religious doctrine in the course of deciding disputes over church property. See Jones v. Wolf, 443 U.S. 595, 602 (1979). Yet even here there is an imperfect analogue in conflicts doctrine, in that courts will sometimes refuse to hear a case in which applying the law that would otherwise be applicable would pose special institutional problems. See Ramirez v. Autobuses Blancos Flecha Roja, S.A. De C.V., 486 F.2d 493, 497 (5th Cir. 1973) (refusing to attempt to apply unfamiliar remedial provisions of foreign law, and dismissing suit without prejudice to bringing of action in different forum). 
that determine when persons are operating within that territory ${ }^{99}$ Establishment of such a territory would set boundaries upon the application of the conflicting legal norms. A claim for a religionbased exemption should therefore be thought of as an assertion that certain behaviour should be governed by the law of the religious territory in which it occurred. ${ }^{100}$

The parallel to territoriality suggests that one interest of the forum state may lead it to reject the religious exemption claim and apply its own law: protection of third parties not subject to the religious authority who would be directly affected by the granting of an exemption. Protection of third parties is distinctive, not because it is the most compelling state interest, ${ }^{101}$ but rather because in the context of relations with third parties, the religious adherent's claim that his conduct should be deemed to be within the jurisdiction of the religious source of authority becomes untenable. Even if a territory for religious concerns has been carved out and the religious proponent is subject to the source of authority for that territory, his action has recrossed the hypothetical boundary, and the place of injury should determine the law to be applied. ${ }^{102}$

99. Cf. Kelley, Confronting the Danger of the Moment, in Church, Srate, and Public Policy 9, 16-17 ( $\mathrm{J}$. Mechling ed. 1978) (discussing concept of "extraterritoriality" to guarantee autonomy for religious institutions).

100. Cf. RESTATEMENT OF CoNfLict of LAws $\$ \S 377-83$ (1934) (tort governed by law of place where it occurred). Modern conflicts doctrine no longer suscribes to as strict a territorial principle. See R. LefLAR, supra note $88, \S 86$, at 173-74 (describing traditional theory of "vested rights" and attacks upon it). Deviations from territorial considerations most often arise, however, when it is arguable that the site of a given event was fortuitous and does not reflect the jurisdiction with which the event has the most significant relationship. See CheshiRe, supra note 88, at 260-63 (discussing principle of "proper law of the tort"); Restatement of Conflicts, supra note 88 , $\$ 145$, Comment e (discussing special problems that arise when location of event is fortuitous). Given that the religious territory assumed for purposes of the analogy is an abstraction, events never occur in it "fortuitously." In any case, conflicts doctrine remains highly territorial in determining the basic wrongfulness of conduct, see Babcock v. Jackson, 12 N.Y.2d 473, 483, 191 N.E.2d 279, 284, 240 N.Y.S.2d 743,751 (1963) (jurisdictions have strong interest in regulating conduct within their borders); Reese, American Trends in Private International Law: Academic and Judicial Manipulation of Choice of Law Rules in Tort Cases, 33 VAND. L. Rev. 717, 736 \& n.46 (1980) (no case is known in which law of state where conduct and injury occurred was not applied to determine whether conduct was tortious), and in its consideration of criminal law and governmental claims, see R. LefLAR, supra note 88 , $\$ \$ 49,115-16$ (rules and qualifications), all of which are subjects that most often generate claims for religion-based exemptions.

101. Under present free exercise doctrine, protection of third parties is recognized by courts as a compelling interest. See, e.g., West Va. State Bd. of Educ. v. Barnette, 319 U.S. 624,630 (1943) (dictum) (state intervention required when freedoms asserted by individuals collide with rights asserted by other individuals); Robert Stigwood Group Ltd. v. O'Reilly, 346 F. Supp. 376, 382-83 (D. Conn. 1972), aff'd, No. 72-1826 (2d Cir. May 30, 1973) (unpublished order) (denying religious defense in suit for copyright infringement); Clark, supra note 15, at 361 (discussing state interest in protecting third parties).

102. Cf. R. LEFLAR, supra note 88 , $\$ 111-114$ (criminal liability for act generally determined by place of injury); Restatment of Conflicts, supra note 88 , $\$ 145$ (rights and lia- 
Any religion-based exemption arguably has effects outside the religious territory. For example, if a religious proponent is exempted from a military draft, another person must arguably be drafted in his place; if he is exempted from paying taxes, the tax burden of other people arguably increases. Such arguments depend, however, upon an assumption that domestic law actually governs the activity in question. The territorial analogy is instructive. In a technical sense, not drafting residents of foreign countries has the effect of requiring more Americans to be drafted in their place. This is not, however, perceived as an injury to any American resident, for it is not assumed that foreigners are being exempted from a law that should apply to them. ${ }^{103}$ The conflicts analogy suggests that persons with claims for religion-based exemptions are much like these foreigners: their claims represent, not dispensations from regulatory schemes, but rather recognition of limits upon the application of those schemes. ${ }^{104}$

Similar analysis justifies ignoring a number of state interests that are ordinarily very important. The conflicts analogy suggests that state interests such as the goals of uniformity and fairness in the application of law, as well as the state interest in preventing persons from compromising their own moral or physical well-being, are relevant to individuals only to the extent that those individuals are perceived to be within the jurisdiction of the state. By carving out a territory for religious concerns, and thereby recognizing circumstances in which religious persons are not within the jurisdiction of the state, the doctrine of competing authorities would make those state interests, not less important, but merely less relevant.

None of the state's interests need be diminished, however, when such territorial carving-out is inappropriate. For all purposes except their specific religious claims, religious persons do remain within the jurisdiction of the state. ${ }^{105}$

bilities in relation to tort usually governed by place of injury, particularly if injured party has significant relationship to that place). In the exemptions context, third parties have a First Amendment right of their own not to be subject to the religious source of authority. Cf. State v. Celmer, 80 N.J. 405, 404 A.2d 1, cert. denied, 444 U.S. 951 (1979) (invalidating conviction by municipal court controlled, under state grant, by religious association).

103. The distinction is similar to that often made between philosophical cause, which is determined merely by the existence of a chain of events, and legally cognizable cause, which is determined by the context of a set of normative expectations. See W. Prosser, LAw OF TORTs $\$ 41$, at 236-37 (4th ed. 1971).

104. Cf. Bittker, Churches, Taxes, and the Constitution, 78 YALE L.J. 1285, 1287-91 (1969) (no more accurate to say that religious institutions are "exempted" from taxation than to say that tax system, by purpose and structure, does not encompass taxation of religious institutions).

105. Thus, when the legislature creates nonpunitive alternative burdens, the courts 


\section{Judicial Application of the Conflicts Approach}

The conflict of laws analogy does not by itself create the specific legal rules necessary for adjudication of exemption claims. The analogy leaves undefined such pivotal concepts as "carving out a religious territory" and "prejudice to third parties." The procedure described below develops the insights of the analogy in order to provide courts with a practical alternative to the current balancing test. The procedure narrows both the scope of cognizable religious claims and the range of state interests that may overcome those cognizable claims, while avoiding the pitfalls of the current test.

\section{A. Cognizable Religious Claims}

The first step of the proposed procedure would be to examine whether a claim to a religion-based exemption was cognizable. The test has three components that, respectively, define the territories of religious concern, determine whether the claimant has significant connections with one of those territories, and decide whether the source of authority perceived to be sovereign in that territory has an interest in the matter.

\section{Religious Systems of Authority}

The argument for religion-based exemptions has here been grounded upon the particular challenge to democratic authority posed by the behavioral, authoritative, and transcendent attributes of religious systems of belief. The test of cognizable religious claims would therefore initially determine whether these attributes, rather than merely individual conscience, were being invoked. In the context of adjudicating exemption claims, religion would be defined as a system of belief, not necessarily theistic or institutional, that contained a source of authority perceived to transcend both the believer and the state. This source of authority must be external to personal belief or philosophy, no matter how strong or sincere, and must have a reality and normative force analogous to that of a foreign government.

This definition would be functional, not theological. ${ }^{106}$ It would limit the scope of cognizable exemption claims by adopting stan-

should enforce them except against those individuals who have legitimate religious objections to the particular alternative burden.

106. Cf. Note, Toward a Constitutional Definition of Religion, 91 Harv. L. Rev. 1056, 1066-67, 1075 (1978) (proposing functional definition of religion drawn from concern for "inviolability of conscience"). 
dards derived directly from the justification for the exemptions. ${ }^{107}$ Systems of belief that did not meet the definition would fail to support claims, not because they were less worthy of respect, but simply because they did not pose the same challenge to democratic authority.

\section{Life Context}

If a religious system of authority were involved, the test would next consider whether the claimant's life context justified his attempt to invoke that authority. One element of this inquiry would involve the screening of fraudulent claims, ${ }^{108}$ especially in situations in which an exemption would be in the person's secular selfinterest. For example, if an ostensible religious group were to appear that objected to payment of any taxes, evidence that it recruited members by promising that they would be able to avoid taxes, and that it had little impact upon their lives other than that promise, would justify denial of an exemption. ${ }^{109}$ In order to prevent the inquiry from acting as a vehicle for inappropriate prejudices, the government would bear the burden of proving fraudulent intent.

Beliefs can be sincerely held, however, without being part of a larger religious commitment. An inquiry into the claimant's life context would therefore include an examination of whether a nexus existed between his particular belief and a general intent to be governed by the religious source of authority. For some religious systems of authority, such an examination could involve an attempt to identify enough overt behaviour to substantiate the proponent's claim, without engaging in an impermissible inquiry into the nature of religious orthodoxy. ${ }^{110}$ Thus, a person who based his

107. The limited purpose of the definition implies that a different meaning could be ascribed to religion for purposes of the general application of the free exercise clause. The establishment clause might require yet a third definition. $C f$. L. TRIBE, supra note $18, \S$ 14-6, at 827-28 (arguing that free exercise and establishment clauses require different definitions of religion); Note, supra note 106, at 1083-86 (same).

108. The standard proposed here is similar in some respects to the sincerity component of present doctrine, United States v. Ballard, 322 U.S. 78 (1944) (court may inquire into good faith, but not truth or falsity of religious belief), but it focuses more narrowly upon an affirmative proof of fraud rather than upon an attempt to measure the intensity of beliefs. $C f$. id. at $92-95$ (Jackson, J., dissenting) (sincerity test dangerous to religious liberty).

109. Similar fraudulent religious claims for the purpose of evading taxes are possible under present tax statutes and have not proved their unworking. Cf. Kurtz, Difficult Definitional Problems in Tax Administration: Religion and Race, 23 CATH. LAw. 301, 305 (1978) (describing scheme to exploit religious exemptions).

110. See p. 360 supra (courts should not try to find essence of particular religion). Courts should not demand that religious behaviour satisfy their perception of consistency. 
claim for exemption upon adherence to a particular tenet of an organized religion that encompassed a collection of distinctive ritual or moral directives, would also have to demonstrate adherence to at least some set of those directives. For other religious systems of belief, which did not lend themselves to such a behaviour-oriented test, the averment of the claimant would often have to suffice. ${ }^{111} \mathrm{~A}$ final prong of the life-context inquiry would be consideration of factors such as childhood ${ }^{112}$ or mental disability ${ }^{113}$ that cast doubt upon the proponent's intent to be subject to the religious system of authority.

\section{Ambit of Religious Authority}

Finally, the test would ask whether the specific religious claim fell within the ambit of the religious source of authority. The test of the religious character of a belief would be whether it was perceived to receive its imperative power from the transcendent religious source of authority: only such a status would pose the particular challenge to democratic authority recognized by the competing authorities justification.

This portion of the test would not involve difficult inquiries into centrality ${ }^{114}$ or into the doctrinal pedigree of particular religious beliefs. ${ }^{15}$ Similarly, a religion's pardon of violation of its laws coerced by conflicting civil law would not justify denial of an exemp-

Cf. Edwards \& Kaplan, Religious Discrimination and the Role of Arbitration under Title VII, 69 MIсH. L. Rev. 599, 615-16 (1971) (citing example of Jews who keep kosher homes but eat nonkosher food away from home).

111. The life-context test is akin to a determination of domicile in conflicts doctrine. $C f$. R. LEFLAR, supra note $88, \S 10$ (discussing requirement of physical presence coinciding with state of mind).

112. Cf. R. LefLAR, supra note $88, \S 12$ (children generally cannot choose their own domicile). Depending upon maturity and intelligence, some minors may be capable of forming an intent to be bound by the religious source of authority. Nevertheless, the state should have the right to use age as a trigger for an inquiry into such capacity. $C f$. Bellotti v. Baird, 443 U.S. 622 (1979) (plurality opinion) (state may require parental consent for minor to obtain abortion, but must provide alternative procedure in which minor can demonstrate to court either that she is mature and well-informed enough to make decision or that abortion would be in her best interests).

113. Cf. R. LEFLAR, supra note $88, \S 13$ (mental incompetent may not have capacity to choose own domicile). As in the case of children, particularized inquiry would be necessary. Cf. Note, Mental Disability and the Right to Vote, 88 YALE L.J. 1644, 1657 (1979) (courts refuse to single out mentally disabled person for distinct treatment unless disability is shown to affect capacity in question).

114. See p. 360 supra (criticizing inquiry into centrality).

115. See note 56 supra (criticizing pedigree tests). A religious community will often perceive part of its ordained duty to be the interpretation of doctrine. See, e.g., J. HoSTETLER, supra note 83, at 58-59 (describing establishment of "ordnung" in Amish church); Dorff, supra note 81 , at $1334-41$ (describing process of interpreting Jewish law). 
tion to adherents of that religion. ${ }^{116}$ The inquiry would, however, exclude claims that were based upon the institutional interests of religious groups rather than upon religious doctrine. ${ }^{117}$

\section{B. Relevant State Interests}

The three-pronged test of religious interests would establish religion-based exemptions as limited and specialized exceptions within the fabric of democratic authority. Nevertheless, one interest of the larger community would overcome even cognizable religious claims: protection of third parties.

The principle of third-party injury would arise in cases of direct prejudice to the legal rights of identifiable third parties who were not subject to the religious source of authority. ${ }^{118} \mathrm{~A}$ general test of

116. See p. 361 supra (criticizing this distinction). Exemptions would be denied if the religion, out of a theological judgment regarding the legitimate role of the state, incorporated all or part of civil law into its religious doctrine. See, e.g., M. LuTHER, Temporal Authority: To What Extent It Should Be Obeyed, in 45 LuTher's Works 75, 92 (Am. ed. 1962) (civil government necessary to bring about external peace and prevent evil deeds); Romans 13:1 ("Let everyone be subject to the higher authorities, for . . . [they] have been appointed by God.") But if the religion excuses violation of religious doctrine because of a conviction that subjection to the civil penalty is a greater evil, or out of a desire to keep peace with the civil authority, that decision should not destroy the religious claim of right. See, e.g., L. Arrington \& D. Bitton, The Mormon Experience 179-84 (1979) (after persecution of Mormons for belief in polygamy, Mormon leaders urged submission to anti-polygamy laws for "temporal salvation of the church"); Christian Science Committee on Publications, Facts About Christian Science 10 (1959), quoted in Note, Compulsory Medical Treatment and the Free Exercise of Religion, 42 IND. L.J. 386, 386 n.2 (1967) (though Christian Scientists obey laws requiring medical treatment of children, they seek legal recognition of right to rely upon Christian Science healing); S. Freehof, A Treasury of Responsa 184 (1962) (some practices otherwise prohibited by Jewish law allowed in order to keep peace with civil authorities).

The problem dealt with here is similar to the question of "renvoi" in conflicts doctrine: whether, in referring to the laws of another state, a court should also look to the choice-oflaw rules of that state. $C f$. RESTATEMENT OF Conflicts, supra note $88, \S 8$ (reference to other state's choice-of-law rules usually not appropriate).

117. Such claims are not justified by the competing-authorities approach, since the religious source of authority, not the religious institution, transcends the state. For example, in Pillar of Fire v. Denver Urban Renewal Auth., 181 Colo. 411, 509 P.2d 1250 (1973), the court attempted to establish standards by which a religious group could prevent condemnation of its church building under the free exercise clause. Those standards, however, relied more upon the historical and sentimental significance of the church building than the specific doctrinal beliefs of the church members. See Note, The Lord Buildeth and the State Taketh Away-Church Condemnation and the Religion Clauses of the First Amendment, $46 \mathrm{U}$. Colo. L. Rev. 43, 50 (1974). The non-entanglement element of establishment clause doctrine should suffice to protect those institutional interests that are necessary to religious liberty. See Serbian E. Orthodox Diocese v. Milivojevich, 426 U.S. 696 (1976) (upholding right of religious group to autonomy in internal government); Walz v. Tax Comm'n of N.Y., 397 U.S. $664(1970$ ) (tax exemption of religious institutions prevents greater evil of excessive entanglement).

118. See p. 368 supra (justifying concern for direct injury to third parties). 
such legal prejudice would be the existence of a hypothetical right of action by that third party against the exempt individual. ${ }^{119}$

The third-party principle would place outside the range of religion-based exemptions crimes and civil wrongs such as murder, trespass, and breach of contract. It would also permit enforcement of social regulations such as fair labor standards and civil rights laws, but only if the religious defendant conducted himself in a market outside the particular religious faith to which he belonged. ${ }^{120}$ Thus, intervention in the consensual relationships of the religious group would unnecessarily invade the territory of religious concern. ${ }^{21}$

The third-party rule would require some qualifications to cope with situations in which the operational test might be misleading. First, absence of an injured third party would not bar prosecutions of attempted crimes. ${ }^{122}$ Second, when the institution of government itself is an injured third party, and not merely a competing source of authority, it should have rights analogous to those of

119. Rights of action are generally created in favor of persons who have been damaged by another's violation of a legal duty. See B. Shipman, Common-Law Pleadings \$ 77, at 196-97 (3d ed. 1923); $c f$. Hodge v. Service Machine Co., 438 F.2d 347, 349 (6th Cir. 1971) (cause of action does not exist until plaintiff suffers legally cognizable damages); Kane v. Nomad Mobile Homes, Inc., 84 Ill. App. 2d 17, 228 N.E.2d 207 (1967) (finding of legal wrong without damage must lead to verdict for defendant).

The private right of action standard would be applied functionally rather than mechanically. The state should not be able to evade it by creating private rights of action when no injury has been sustained. Conversely, if a private right of action were barred for some procedural reason, it would not cease to be a "hypothetical right of action." The existence of a private right of action would trigger the state's right to pursue whatever remedies are available to it. Allowing the state to intervene would be necessary to afford the potentially injured party his full measure of protection.

120. In Brown v. Dade Christian Schools, Inc., 556 F.2d 310 (5th Cir. 1977), cert. denied, 434 U.S. 1063 (1978), a racially segregated private religious school attempted to block a private civil rights action under 42 U.S.C. $\$ 1981$ (1976). The Court held that the discriminatory practices of the school were matters of policy rather than religion. Id. at 313 . A concurring opinion argued that the belief was religious, but was overcome by a compelling state interest. $I d$. at 320,322 . The procedure proposed in this Note would have allowed the court to focus more directly on evidence that the school's students were not limited to those in families of church members and that the school advertised in the "yellow pages." Id. at 311 .

121. The territoriality metaphor is especially appropriate in considering such relationships: a group of persons has voluntarily entered a sphere in which their rights and obligations are determined by a distinct set of legal norms. Cf. Note, Title VII and the Appointment of Women Clergy: A Statutory and Constitutional Quagmire, 13 Colum. J.L. \& Soc. Prob. 257, 286-88 (1977) (women seeking to become priests have impliedly consented to their religion's discriminatory practices).

122. This exception is justified by the same rationale that underlies the crime of attempt itself: if a person has substantially completed an effort to commit a punishable act, the state should not have to wait for him to cause actual injury before it can stop him and take punitive measures. See W. LaFave \& A. Scotr, Criminal. Law \$ 59, at 426-27 (1972). 
other persons. ${ }^{123}$ Finally, the existence of a legally prejudiced third party should in some cases be insufficient to deny an exemption. This is most obvious when the injury to the third party is minimal or nominal. ${ }^{124}$ This third caveat would also apply when the primary purpose of the legal rule was to influence the behaviour of the religious proponent rather than to do justice to the third party, ${ }^{125}$ or when a religion-based exemption could, without undue distortion, be justified by the logic of the relevant legal standard. ${ }^{126}$

\section{Comparative Advantages of the Proposed Test}

The new procedure would not be a mere variant of the balancing test; rather, a claim of exemption would be recognized only if it passed the test of religious interest and did not fall into the concrete and limited category of government interest. The proposed test addresses the distinctive features of the exemption context and overcomes the specific failures that dominate current doctrine. First, the theoretical underpinnings of the test suggest responses to basic objections that religion-based exemptions are inconsistent with the rule of law, notions of equal treatment, and the establishment clause. To the extent that the analysis uncovers limits upon the application of domestic law, and argues for deference to other legal systems, the rule of law is left uncompromised. To the extent that religious persons are potentially subject to two systems of authority, the goal of equal treatment within one of those systems can

123. Cf. Note, Protecting the Public Interest: Nonstatutory Suits by the United States, 89 Yale L.J. 118, 120-21 (1979) (distinguishing government rights of action analogous to those afforded private parties from other government interests to which parallel cannot be applied). Thus, theft from the government is as much a direct injury to an identifiable third party as theft from a private individual. Furthermore, the fact that a crime against the institution of government is separately enumerated, and perhaps defined or punished in a way not completely parallel to crimes against private individuals, should not affect the state's right to protect itself against direct injury. Thus, prosecution for conversion of government property, forgery of government documents, and similar acts should not be blocked by religion-based exemptions.

124. Cf. TWA v. Hardison, 432 U.S. 63 (1977) (statute requiring employers to make "reasonable accommodations" to employee's religious beliefs does not require more than minimal expenditures or disruption of procedures).

Such a de minimis standard would isolate those circumstances in which private rights of action do not reflect true direct injury. See note 119 supra (discussing usual meaning of "right of action"). The exemption would be a narrow one so as to avoid reintroducing a balancing test to the procedure.

125. In such cases, the relevant norm is that imposed by religious law. $C f$. Restatement of Conflicts, supra note 88, $\$ 145$, Comment c (distinguishing deterrence and compensation purposes of tort rules).

126. Cf. Note, Medical Care, Freedom of Religion, and Mitigation of Damages, 87 Yale L.J. $1466,1479-81$ (1978) (allowing religion-based exemption to mitigation of damages requirement in tort suits would conform to principles of underlying requirement). 
reasonably give way to a just accommodation between them. Finally, to the extent that exemptions are characterized as responses to one of the dilemmas of a legally heterogeneous world, rather than as gratuitous preferences for the consciences of religious persons, the establishment clause is not seriously threatened.127

Second, unlike current doctrine, the proposed test does not resort to weighing of the relative importance of every law from which an exemption is claimed. Rather, it categorizes laws by use of functional arguments tied to an underlying analysis unrelated to particular legislative judgments.

Third, the test does not intrude excessively upon religious autonomy. The test establishes standards for cognizable religious claims, but once a claim meets those standards, its religious character is not subject to further weighing and probing. The standards themselves are straightforward and functional, and they avoid intrusive inquiries into centrality or doctrinal pedigree. Moreover, the test is concerned with vindicating religious claims of right, rather than monitoring how much suffering particular laws cause individuals.

Finally, the clear parameters established by the proposed test would reduce the probability of ill-conceived or biased decisions. Factual uncertainties and borderline cases would still arise, but their difficulty would be minimized by the combination of a clear underlying theory and a specific set of legal standards.

127. No doctrine of religion-based exemptions could satisfy adherents of the view that the establishment clause forbids government from ever taking religion into account. $C f$. Kurland, supra note 44, at 95-96 (advocating "strict neutrality"). But the Supreme Court has never adopted this absolutist position. See L. TRIEE, supra note 18, § 14-4, at 820-21. The competing authorities approach does, however, demonstrate the particular challenge posed by religious claims for exemptions, $c f$. Walz v. Tax Comm'n of N.Y., 397 U.S. 664 (1970) (statutory tax exemptions of religious institutions permissible because they prevent greater harm of excessive entanglement), while placing those exemptions in a context that renders them less anomalous and gratuitous, $f f$. Bittker, supra note 104, at 1295 (nonprofit institutions other than religious institutions also receive statutory tax exemptions). 